\title{
ソーシャルメディア上の行為に基づく興味予測
}

\section{Interest Prediction via Users' Actions on Social Media}

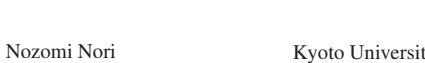 \\ nozomi@ml.ist.i.kyoto-u.ac.jp \\ ボレ゙ガラ \\ Danushka Bollegal \\ リヴァプール大学 \\ University of Liverpool \\ danushka.bollegala@liverpool.ac.uk \\ 石塚 満 \\ 早稲田大学 \\ Waseda University \\ ishizuka@aoni.waseda.jp
}

keywords: social media, interest prediction, user modeling, graph, collaborative filtering

\begin{abstract}
Summary
We propose a method to predict users' interests by exploiting their various actions in social media. Actions performed by users in social media such as Twitter and Facebook have a fundamental property: user action involves multiple entities - e.g. sharing URLs with friends, bookmarking and tagging web pages, clicking a favorite button on a friend's post etc. Consequently, it is appropriate to represent each user's action at some point in time as a higher-order relation. We propose ActionGraph, a novel graph representation to model users' higher-order actions. Each action performed by a user at some time point is represented by an action node. ActionGraph is a bipartite graph whose edges connect an action node to its involving entities, referred to as object nodes. Using real-world social media data, we empirically justify the proposed graph structure. We show that the prediction accuracy can be improved by adequately aggregating various actions. Moreover, our experimental results show that the proposed ActionGraph outperforms several baselines, including standard tensor analysis PARAFAC, a previously proposed state-of-the-art LDA-based method and other graph-based variants, in a user interest prediction task. Although a lot of research have been conducted to capture similarity between users or between users and resources by using graph, our paper indicates that an important factor for the prediction performance of the graph mining algorithm is the choice of the graph itself. In particular, our result indicates that in order to predict users activities, adding more specific information about users activities such as types of activities makes the graph mining algorithm more effective.
\end{abstract}

\section{1. は じめに}

$1 \cdot 1$ ソーシャルメディア上での人々の様々な行為データ の応用可能性

近年人々は情報を得たり共有したりする目的でソーシャ ルメディア上で他者と樣々な関係を構築するようになっ ており，㫕のソーシャルネットワーク上でURL への言 及やテキストの引用, 再発信を行ったり, URL で特定さ れるような，画像やマイクロブログの投稿といったよう なウェブ上の樣々なリソースに対してタグ付けを行った りと樣々な行為を行うようになった . ユーザがハイパー リンクを用いてドキュメントを参照することでドキュメ ント同士か関連付けられていくことがウェブの大きな特 徵であるが, 現在のウェブが持っている面として, ソー シャルメディアの普及を背景として，より一般に人々の 樣々な行為によって樣々なリソースか関連付けられるよ うになっている点が挙げられる．
ユーザの行為は樣々なリソースを関連付けるだけでな く，行為主体であるユーザの嗜好や興味を反映している と期待できるため，これらユーザの行為データを活用す ることでウェブの樣々なアプリケーションを改善する取 り組みがなされてきた . 例えばユーザのタグ付けデータ は個人化された検索 [Bao 07, Heymann 08, Xu 08] や人 間関係の推論 [Schifanella 10] , 新たなオントロジーの発 見 [Mika 05]などのタスクに有効であることが指摘され ている。

\section{$1 \cdot 2$ ユーザの興味予測とその課題}

ユーザがあるリソースに対して何らかの行為を行った とき，弚のユーザが炎のリソースに対して好意を抱いた のか疑問を抱いたのかなどは明らかではないが , 少なく とも光のリソースに何らかの興味を抱いたと捉えること ができるだろう . 本論文では, ユーザがどのようなリソー スに対して行為を行うかを予測する問題としてユーザの 
興味予測を定義しこの問題に取り組む．

近年は , ソーシャルメディアの普及によりユーザが樣々 なウェブサービスを用いて樣々な行為を行うようになった ことを背景に，ユーザの樣々な行為を活用した上でユー ザの興味を予測する研究が盛んに取り組まれている．例 としては, ユーザがソーシャルネットワーク上で持つ他の ユーザとの関係や樣々なアイテムと持つ関係をもとにユー ザの興味予測やアイテム推薦を行う研究 [Jiang 12, Ma 11, Yang 11] が挙げられる.これらの研究では, 例えば ユーザが言及するニュース記事を予測するのにユーザの ソーシャルネットワークを用いるといったように, 実際 に予測する対象の行為と異なる種類の行為も予測に活用 している. 䒓の背景には, 異なる種類の行為であっても， 対象 (ユーザ) に対する相補的な性質を反映していると 考えられるため予測に活用できるであろうという期待が ある .

以上のように, ユーザの樣々な行為を活用した上でユー ザの興味を予測する研究は近年盛んに行われているもの の，以下の二点の課題があると著者らは考える . 一点目 は，(1) 樣々なウェブサービス上の樣々な行為データを ユーザの興味予測に活用できるのか, 光れはどのような 場合かといった問に答えるために定量的分析を行うこと である.ユーザの興味予測に関する研究は数多くなされ ているが, ウェブサービスをまたぐような研究は少なく， 特に，異なるウェブサービスをまたいでも異なる種類の 行為を興味予測に活用できるのかといった点に答える定 量的分析はほとんど行われていない．この背景には，従 来は異なるウェブサービス間でユーザの同一性判定を行 うことが難しく，異なるウェブサービスをまたいだユー ザの興味予測という問題の応用可能性が限定されていた ことなどがあると考えられる。しかし，昨今では Twitter， Facebook, Foursquare など樣々なサービス間でAPI 連携 が行われており，異なるサービスを同時に利用するユー ザも増え, ユーザの同一性判定が比較的行い易くなって きており, 異なるウェブサービスをまたいだユーザの興 味予測という問題の応用可能性が広がっていると考えら れる．したがって，上記の問に答えるために定量的分析 を行うことは重要な課題となる .

二点目は, (2) ユーザの行為データを多項関係データ として扱った上で, ユーザの興味を予測する必要がある ということである．上記で言及した研究を含め，ユーザ の樣々な行為を活用した上でユーザの興味を予測する研 究において一般的なアプローチは, ユーザの行為をユー ザとアイテム間のような二項関係として捉えるものであ る. 例えば，推薦システム等で普及している協調フィル タリング [Resnick 94, Shardanand 95] の基本的な枠組み は，あるユーザと似た興味を持つ他のユーザが気に入る アイテムを兴のユーザに推薦することであるが , 従来は ユーザの興味はどのアイテムに (購入などの) 行為を行っ たかのみをもとに判断されることが多かった．しかしな
がら, ユーザの行為は, より一般には, ユーザ, リソー ス , キーワードなど複数のオブジェクトを巻き込む多項 関係データとして捉えられるので, ユーザの樣々な行為 データを多項関係として活用した上でユーザの興味を予 測する必要があるだろう．また，ウェブ上のユーザやリ ソースは大量にあるため, これらを巻き込む多項関係か らユーザの興味を的確に予測するためにはデータ過疎に 頑健な予測手法が必要となる.

\section{3 アプローチ}

一つ目の課題に対しては, retweet などの特定の種類の 行為を予測するのに, 各行為を特徵ベクトルで表現した 際の特徵量を共有する別の種類 (例えばfavorite) の行為 データを用いた場合にもともとの種類の行為データを用 いた場合と同程度の精度が実現できるのか炎うでないの かを評価した . ある種類の行為を予測するのに別の種類 の行為データを用いても同程度に高い精度が実現できる ならば, データが過疎な場合などに光れら複数種類の行 為データを活用することで, ユーザの興味予測の性能向 上が期待できるだろう．

二つ目の課題に対しては, まず, 人々のウェブ上の樣々 な行為を多項関係として汎用的に表現した上で, 多項関 係の共起情報を欠損させることなく二項関係に変換する ことで, 協調フィルタリングの基本的アイデアを今回の 問題に沿うように拡張した . これを可能にするアクショ ングラフという, ユーザの樣々な行為を多項関係として 表現できる新しいグラフ表現を提案し，弚のグラフを用 いた予測手法を提案した。

\section{4 本論文の貢献}

以下で本論文の貢献について述べる .

(1) 樣々なウェブサービス上の樣々な行為データをユー ザの興味予測に活用できるのか, 乥れはどのような場合 かといった問に答えるための定量的分析を行った . 具体 的には, ある種類の行為を予測するのに異なる種類の行 為データを活用することで, もともとの種類の行為デー タを用いた場合と同程度の精度が実現できるのか光うで ないのかを評価する実験を実データを用いて行い，いく つかの知見を得た . (2) ユーザの樣々な行為を多項関係 として表現できる新しいグラフ表現としてアクショング ラフを提案し，弚のグラフを用いた予測手法を提案した。 (3) 現実のソーシャルメディアのデータを用いた実験によ り, 提案手法の有効性を既存の樣々な手法と比較し評価 した . 特に, 予測精度やデータ過疎への頑健性といった 観点て評価した際に, 提案手法はテンソルの標準的分解 手法である PARAFAC や二項関係に対する LDA , 構築 しているグラフ構造のみ異なるが提案手法と同一のアル ゴリズムを適用した樣々なベースラインを上回る性能を 示すことを確認した . (4) ユーザ間の類似度やユーザと 
リソースの間の類似度をグラフを用いて計算する手法は これまで多々提案されてきたが，一連の評価実験により， グラフを用いたアルゴリズムの性能は光も光もどのよう なグラフを構築するかに依存するという示唆を得た . ま た , ユーザの行動に関与する樣々なエンティティの情報 をグラフに付与することで, グラフマイニングのアルゴ リズムを効果的に機能させることができるという示唆を 得た。

\section{$1 \cdot 5$ 本論文の構成}

本論文の以降の構成について述べる.2 章では, 樣々な ウェブサービス上の樣々な行為データをユーザの興味予 測に活用できるのか, 弚れはどのような場合かといった 問に答えるために行った実験について記述する ここれは 既存のロジスティック回帰を用いた分析である.続く 3 章 では, ユーザの興味予測のための手法を提案する.ユー ザの樣々な行為を多項関係として表現できる新しいグラ フ表現としてアクショングラフを提案し,さらにアクショ ングラフを用いた予測手法について説明する .4 章では， ユーザの興味予測タスクにおいて提案のアクショングラ フの性能を評価するために行った実験について記述する． 5 章で関連研究について述へ，本研究の位置付けを明確 にする . 最後に 6 章でまとめを行う .

\section{2. ソーシャルメディア上のユーザの行為の分析}

ここでは, 樣々なウェブサービス上の樣々な行為デー タをユーザの興味予測に活用できるのか, 光れはどのよ うな場合かといった問に答えるために，ある種類の行為 を予測するのに，異なる種類の行為データを用いること ができるかを評価する実験を行う.例えば, Delicious 上 のタグ付け行為や Twitter 上の retweet 行為を使うことで Twitter における favorite 行為をどの程度正確に予測する ことができるだろうか. もし元々のfavorite データを用 いるのと同程度に良い精度で予測できるのであれば，こ れらの行為に反映されているユーザの嗜好には共通部分 が存在すると考えられるので, これらの異なる行為デー タを用いることはユーザの興味予測に有効であると言え るだろう . 実験を行った結論としては, 異なる種類の行為 データを活用することで，いくつかの場合において，元 の種類の行為のみを用いた場合と同程度の予測精度を実 現できることが確認された . 以下で実験条件と結果につ いて述べる。

\section{$2 \cdot 1$ 実 験 条 件} データセット

Twitter*1 と Delicious*2 という二つのサービスからデー タを収集した .我々は異なるウェブサービスやアプリケー

*1 twitter.com

$* 2$ delicious.com
ションからのデータを組み合わせることを目指している ので , 異なるウェブサービスやアプリケーションを“橋 渡しする”もしくは “つなげる”ようなエンティティが必 要である . URL はまさに弚のようなエンティティとし て考えることができる．加えて，URL はウェブ上の樣々 なリソースを参照することができるので, ユーザの興味 の対象を表現するのにも適している。したがって，URL を含むような行為を分析の対象にすることが望ましいだ ろう. Twitter における主要な機能である tweet, retweet, favorite はこの要件を満たす．またfollow はこれらの行 為の背景にあるソーシャルネットワークを作る行為であ るので, 以上の四つを Twitter 上の行為として分析対象と した . 以下でこれらの機能を簡単に説明する . Twitter 上 ではユーザは tweet と呼ばれる短いテキストを投稿する ことができ，この投稿中には URL を含めることもでき る.他のユーザを follow することで觉のユーザの投稿を 自身のタイムラインに表示することができる．他のユ一 ザの投稿を retweet することで, 弚の tweet を再発信する ことができる．ある投稿を retweet することで, 弚のユ一 ザをfollow しているユーザのタイムラインに元の tweet が表示されるようになる.ユーザはまた他のユーザの投 稿に対してfavorite することができ，これはお気に入り のような意味合いを持つ .

Twitter 上の特定のユーザを起点にし，フォローネット ワークを 2 ホップ先まで辿ることで, ユーザの候補集合 を得た . 更に異なるアプリケーションのデータを橋渡しす るためにはユーザの同一性判定も行えることか望ましい が, 乥れは FriendFeed ${ }^{* 3}$ というウェブアプリケーション のアグリゲートサービスを用いることで可能になる．し たがって，上記で得られたユーザ集合の中でFriendFeed のアカウントを保有しているユーザを自動的に特定し， 行為主体のユーザ集合として 3,356 人のユーザを得，光 れらのユーザが 2010 年の 8 月 1 日から 8 月 30 日の間 に Twitter 上で行った各行為を分析対象のデータとした . この 3,356 人のユーザが，本実験で対象とした全ユーザ 集合である．また，本実験では Twitter の他に Delicious と呼ばれるブックマークサービスにおけるタグ付け行為 を分析の対象に含めた . Delicious におけるタグ付け行為 は，あるユーザがウェブ上のリソースに対して任意のタ グを付ける行為であり，リソースを参照するのにURL が 用いられている . 上記で得た 3,356 人のユーザ集合の中 で Delicious におけるアカウントも保有し，かつ上記期 間中に Delicious 上での行為か確認されたユーザ 151 人 を特定し, Deliciousにおける行為データも取得した .

各行為の特徵量と, 兴のデータサイズについては表 1 にまとめた . 各行為の種類 tweet, retweet, favorite, follow, tag に対して, 兴の簡略表現として兴れ光れ Tw, RT, Fav, Fol, Tag という表記を追記した .この簡略表現を 以降の結果に関する図表中で用いる . original tweet は，

\footnotetext{
*3 friendfeed.com
} 
表 1 ソーシャルメディア上のユーザの行為分析実験で用いたデー 夕の概要

\begin{tabular}{|c|c|c|c|}
\hline 行為の種類 & 行為の数 & エンティティ & エンティティの数 \\
\hline tweet (Tw) & 213,929 & ユーザ & 3,032 \\
& & URL & 147,686 \\
\hline retweet (RT) & 22,680 & ユーザ & 1,908 \\
& & URL & 16,931 \\
& & original tweet & 20,557 \\
\hline favorite (Fav) & \multirow{2}{*}{37,912} & ユーザ & 1,693 \\
& & URL & 28,392 \\
& & original tweet & 35,018 \\
\hline follow (Fol) & \multirow{2}{*}{214,561} & フォローしているユーザ & 2,894 \\
& & フォローされているユーザ & 3,198 \\
\hline tag (TAG) & \multirow{2}{*}{21,530} & ユーザ & 151 \\
& & URL & 7,938 \\
& & tag & 3,033 \\
\hline
\end{tabular}

retweet/favorite の行為における元の tweet の ID の文字 列である . ユーザは一つのリソースに対して複数のタグ を用いることができるので, 複数のタグが用いられた場 合には個々のタグを一つの特徵量として全体として複数 の特徵量を用いた . ロジスティック回帰の入力には, 表 1 のエンティティの他, 各行為について产の行為の種類を 特徵量として用いた。また, tweet と retweet/favoriteで original tweet の特徵量が共有されるよう, tweet におい ては自身の tweet の ID の文字列も特徵量として用いた . また，各行為について行為数に関するユーザ分布を図 1 に両対数グラフで示した . 各図で, 横軸は行為数を表し, 縦軸は, 弚のような行為数であるユーザの数を表す． 予測設定

各行為は表 1 に示されている特徵量で表現されるもの とする . 30 日間のデータを 3 日ごとに区切った 10 個の スロットを作り，スロット $t \in[1, \ldots, 9]$ のデータを訓練 データとして钅の行為が実際に行われるかどうかを判定 する分類器を構築し, 構築した分類器を用いてスロット $t+1 \in[2, \ldots, 10]$ の評価データを分類した . 今回はユー ザや URL を共有するようにデータセットを構築してい るので, 異なる種類の行為同士で一定の特徵量が共有さ れている.

以上の予測設定の下, ある種類の行為を予測するのに， 同じ種類の行為を用いる場合と異なる種類の行為を用い る場合の关れ光れで予測精度がどう変わるかを評価した。 例えば tag 行為について与えられた評価データを, 評価 データと同じ種類の行為（tag）と異なる種類の行為デー タ (tweet, favorite, retweet, follow) ぞれどれを訓練デー タとして用いて構築した分類器で正例か負例かを判定す る二值分類を行い, 光の精度を評価した . 各訓練データ および評価データについて $50 \%$ の負例をランダムに作成 した . 学習には L2 正則化ロジスティック回帰を採用し， 最適化にあたっては Limited-memory Broyden-FletcherGoldfarb-Shanno (L-BFGS) [Nocedal 80] を用いた . 実装 には Classias*4 と呼ばれるライブラリを用いた . 正則化項 の係数は 1 で統一した . 行為の種類によってデータ量が

\footnotetext{
*4 chokkan.org/software/classias/index.html
}
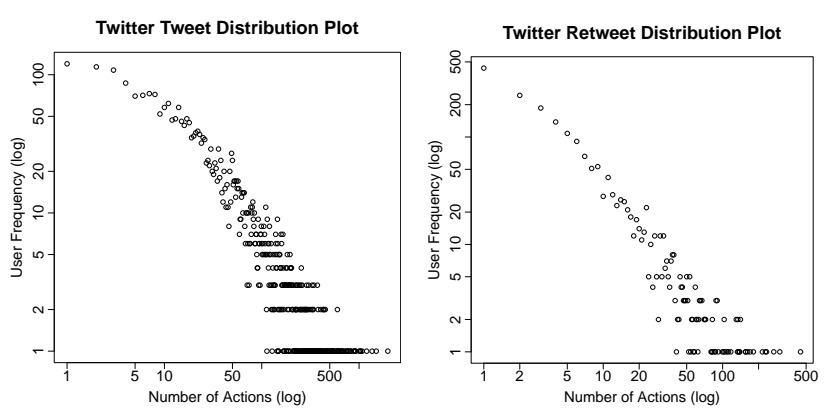

(a) tweet 行為数のユーザ分布

(b) retweet 行為数のユーザ分布
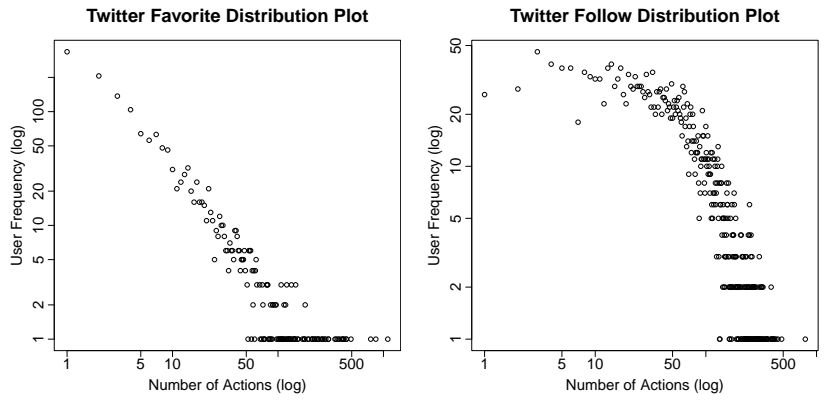

(c) favorite 行為数のユーザ分布

(d) follow 行為数のユーザ分布

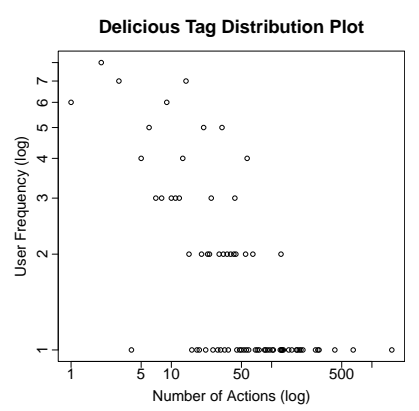

(e) $t a g$ 行為数のユーザ分布

図 1 各行為について行為数に関するユーザ分布

異なるので , データ量の差によって生じる精度差の影響 を緩和するために, 各スロットの各訓練データ/評価デー 夕の量 (学習/評価に用いる入力データ数) は異なる行為 種類であっても同量になるように調整した .

\section{$2 \cdot 2$ 結果}

全結果を表 2 に記した. 特に以下の考察で図 2, 図 3, 図 4 で表示した結果に対応する結果については表中で太 字で表示している . 以下でこの結果から得られるいくつ かの考察を記す。

複数のウェブサービスにおける補足的な特徵量

図 2 は Twitter 上の行為をDelicious の tag 行為を用い て予測した場合と Twitter 上の元の行為を用いて予測し た場合の実験結果の比較を, 図 3 は Delicious の tag 行為 を Twitterの行為を用いて予測した場合と Delicious 上の 元の行為を用いて予測した場合の実験結果の比較を示し ている $. A-B$ で示される各棒グラフは, 評価データの 行為の種類が $A$ であり訓練データの行為の種類が $B$ で あるような実験条件での予測精度の平均值を示しており， 
エラーバーは標準偏差を示している .この描画方法は以 降の図で共通である。

例えば，図 2 の 6 本目のバーに対応するのは，Twitter 上のfavorite 行為を Delicious 上のtag を用いて予測する 実験の結果であるが，これは，訓練データとして上記で 説明した特徵量によって表現される $\operatorname{tag}$ のデータを用い， 弚のデータで学習した L2 正則化ロジスティック回帰の モデルで，上記で説明した特徵量で示される favorite の 各行為を正例か負例かに二值分類する実験のことである 图 2 から, Delicious の tag を用いることは, Twitterの favorite やfollow の行為の予測に有効であることが確認 できる favorite 自身を用いてfavorite を予測するよりも， tag を用いて favorite を予測する方が平均値としては高い 精度を実現している . 同樣のことがfavorite をfollow に 置き換えても言える .このことは, Delicious の tag 行為 は Twitter の favoriteやfollow 行為の代わりに用いるこ とができること，すなわち favoriteや follow のデータが 過疎であるときに他の種類の行為データとして tag の行 為データを活用することができることを示唆している．

一方で, 逆に Twitter 上の行為を用いて Delicious 上の 行為を予測する実験では，図 3 で示されているように上 記のようなことは言えない. Twitter 上の行為を用いて Delicious 上の行為を予測した場合，Delicious 上の行為 を用いて予測した場合と比べて総じて低い予測精度となっ ている。

これは複数のドメイン (ウェブサービスやアプリケー ション) における非対称な性質と言えるだろう，我々の 実験では, Delicious の tag 行為が Twitter 上のいくつか の行為を予測するのに有効であった一方で, Twitter の行 為データは Delicious の tag 行為を予測するのに有効では なかった．この理由としては，キーワード (タグ付け行 為で使われたタグ) は，キーワードを含まない行為に反 映されている嗜好に補足的な嗜好を反映していることが 考えられる。例えばfavorite に反映されている嗜好を説 明する際には, favorite 行為から直接的に観測できる特徵 量 (ここでは行為主体のユーザや言及されている URL) だけでなく，エンティティ(行為主体ユーザや言及される URL) を共有する $\operatorname{tag}$ 行為から観測される特徵量 (キー ワード）を用いることで，元の嗜好を補足することがで きると考えられる . 以上のことから, 異なるウェブサービ ス, アプリケーション間であってもユーザの行為データ をアグリゲートすることが有効であることが示唆される . 類似した行為の種類

図 4 に,tweet/retweet から tweet/retweet を予測する実 験結果を示した . 图から，一方の種類の行為を予測する のに他方の種類の行為を用いても同等の結果になってい ることが確認できる .このことは, 上記で述べたのと同 樣に , 一方のデータが過疎であるときに他方のデータを 活用することができることを示唆している．ある種類の 行為 $A$ を予測するのに別の種類の行為 $B$ を活用するこ

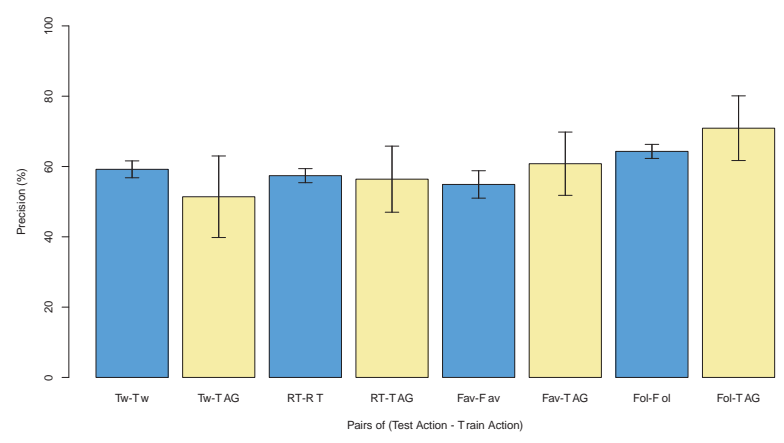

図 2 Twitter の行為を Delicious の tag 行為から予測する実験

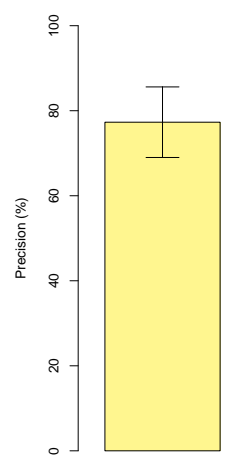

TAG-TAG

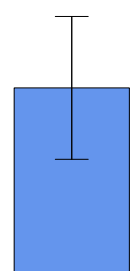

TAG-Tw

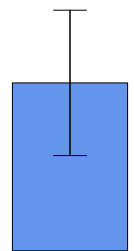

TAG-RT

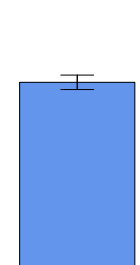

TAG-Fav

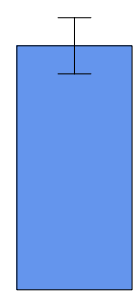

Tag-F ol
図 3 Delicious の tag 行為を Twitter の行為から予測する実験

とができるとき，行為 $A$ と $B$ に反映されている嗜好は 共通部分を持つと考えられる. 行為 $B$ を予測するのにも 行為 $A$ を活用することができるとき，行為 $A$ と $B$ は互 いに類似していると言えるだろう. 今回対象とした行為 の中では tweet と retweet の行為が相対的に類似してい た .この二つの行為はどちらも自身をフォローしている ユーザに対してあるURL を発信していると言え，これ は他の行為にはない性質である.

類似していない行為の種類

一方で表 2 中で, follow 行為を他の種類の行為を用い て予測した場合や，乥の逆にfollow を用いて他の行為を 予測した場合から確認できるように，他の種類の行為が 有効に活用できない場合も存在する . 上記の多くの場合 において，他の種類の行為を用いても，元の行為を用い た場合よりも総じて低い精度しか実現できていない。

\section{URL を言及する行為の類似性}

表 2 から，Twitterにおける URLを言及する行為(tweet, retweet, favorite) は相対的に互いに類似していることが 確認できる.URL を言及する行為を予測するには,follow を用いるよりも他のURL を言及する行為を用いる方が 多くの場合で高い精度を実現する .これは，Twitter にお いて URL を言及する行為に反映されている嗜好は相対 的に互いに類似しているためと考えられる.上記の考察 と同樣に，URL を言及する行為データが過疎であるとき には他のURL を言及する行為データを活用できること が示唆される .

最後に , ウェブサービス上の行為が Twitter 上に反映 
される機能を持つようなウェブサービスも存在するため， 产のようなサービス間の相互作用の効果に関する分析を 行うことも今後の重要な課題と考えられる.

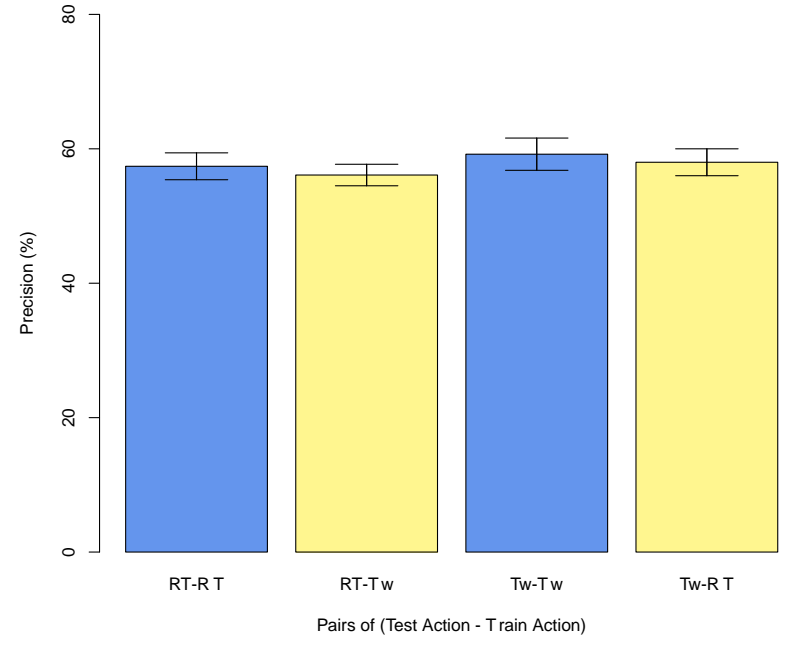

図 4 tweet/retweet から tweet/retweet を予測する実験

\section{3. 提 案 手 法}

2 章で行った分析から，ユーザの樣々な行為を興味予 測に活用できることが示唆された。したがって，ユーザ の興味予測においては, ユーザの樣々な行為を活用する 手法が有効であると期待される . 本章ではユーザの樣々 な行為を活用したユーザの興味予測のための手法を提案 する .

\section{$3 \cdot 1$ アクショングラフの構築}

ここでは, ユーザの樣々な行為を多項関係として表現 できるグラフであるアクショングラフを提案する．以下 で, 例を用いてアクショングラフの構築方法について述 ベる .

ソーシャルメディア上でのユーザの行為はしばしば複 数のエンティティを巻き込む . 例えばあるユーザ $A$ があ るURL $l$ で参照されるウェブサイトに対して “人工知能” というタグを付ける状況を想定してみる．この行為には 四つのエンティティか関与していると考えることができ るだろう .すなわち, ユーザ $A, \mathrm{URL} l$, 行為の種類とし ての“タグ付け”，光してキーワード“人工知能”である． この行為を表現するために，我々はこの行為弚れ自体を 表現する一つのアクションノードを生成し，さらに上記 四つのエンティティ, ユーザ $A, \operatorname{URL} l$ ，キーワード“人 工知能”, 行為の種類 “タグ付け”に相当する四つのオブ ジェクトノードを生成する．続いてこのアクションノー

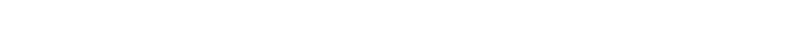
エッジを張る。

我々が提案するアクショングラフは重みなし無向二部 グラフ $G=\left(V_{O B} \cup V_{A C}, E\right)$ として定義される.

エンティティの総数を $m$, 行為の総数を $k$ とすると
表 2 ソーシャルメディア分析実験における予測精度（各スロット での平均と標準偏差

\begin{tabular}{|c|c|c|}
\hline 評価に用いた行為 & 訓練に用いた二行為 & 精度 \\
\hline TAG & TAG & $\overline{777.3 \pm 8.3 \%}$ \\
\hline TAG & Fav & $43.4 \pm 1.7 \%$ \\
\hline TAG & Fol & $\mathbf{5 7 . 4} \pm \mathbf{6 . 6} \%$ \\
\hline TAG & RT & $39.5 \pm 17.1 \%$ \\
\hline TAG & Tw & $43.5 \pm 16.8 \%$ \\
\hline Fav & Fav & $54.9 \pm \mathbf{3 . 9} \%$ \\
\hline Fav & Fol & $49.5 \pm 2.4 \%$ \\
\hline Fav & RT & $53.0 \pm 3.3 \%$ \\
\hline Fav & $\mathrm{Tw}$ & $51.6 \pm 2.4 \%$ \\
\hline Fav & TAG & $\mathbf{6 0 . 8} \pm \mathbf{9 . 0} \%$ \\
\hline Fav & Tw-Fol & $50.5 \pm 1.5 \%$ \\
\hline Fav & Fav-Fol & $53.3 \pm 1.9 \%$ \\
\hline Fav & Fav-RT & $55.9 \pm 2.9 \%$ \\
\hline Fav & Fav-Tw & $55.0 \pm 3.1 \%$ \\
\hline Fav & RT-Fol & $51.2 \pm 1.2 \%$ \\
\hline Fav & RT-Tw & $52.5 \pm 2.5 \%$ \\
\hline Fav & Fav-RT-Fol & $54.7 \pm 2.4 \%$ \\
\hline Fav & Fav-RT-Tw & $55.3 \pm 3.0 \%$ \\
\hline Fav & Fav-Tw-Fol & $53.9 \pm 1.8 \%$ \\
\hline Fav & RT-Tw-Fol & $51.2 \pm 1.8 \%$ \\
\hline Fav & Fav-RT-Tw-Fol & $54.5 \pm 2.2 \%$ \\
\hline Fol & Fav & $55.0 \pm 3.6 \%$ \\
\hline Fol & Fol & $64.3 \pm 2.0 \%$ \\
\hline Fol & $\begin{array}{ll}\text { RT } \\
\end{array}$ & $52.4 \pm 3.4 \%$ \\
\hline Fol & $\mathrm{Tw}$ & $53.2 \pm 2.3 \%$ \\
\hline Fol & TAG & $70.9 \pm 9.2 \%$ \\
\hline Fol & Tw-Fol & $62.9 \pm 2.3 \%$ \\
\hline Fol & Fav-Fol & $63.5 \pm 1.8 \%$ \\
\hline Fol & Fav-RT & $51.7 \pm 2.9 \%$ \\
\hline Fol & Fav-Tw & $52.8 \pm 2.5 \%$ \\
\hline Fol & RT-Fol & $63.2 \pm 2.3 \%$ \\
\hline Fol & RT-Tw & $52.0 \pm 2.8 \%$ \\
\hline Fol & Fav-RT-Fol & $62.4 \pm 2.2 \%$ \\
\hline Fol & Fav-RT-Tw & $51.5 \pm 2.8 \%$ \\
\hline Fol & Fav-Tw-Fol & $62.2 \pm 2.1 \%$ \\
\hline Fol & RT-Tw-Fol & $62.2 \pm 2.0 \%$ \\
\hline Fol & Fav-RT-Tw-Fol & $61.7 \pm 1.8 \%$ \\
\hline$\overline{\mathrm{RT}}$ & Fav & $\overline{53.7 \pm 2.6 \%}$ \\
\hline RT & Fol & $50.8 \pm 1.5 \%$ \\
\hline RT & RT & $57.4 \pm \mathbf{2 . 0} \%$ \\
\hline RT & $\mathrm{Tw}$ & $56.1 \pm 1.6 \%$ \\
\hline RT & TAG & $56.4 \pm 9.4 \%$ \\
\hline RT & Tw-Fol & $52.7 \pm 1.1 \%$ \\
\hline RT & Fav-Fol & $52.0 \pm 1.1 \%$ \\
\hline RT & Fav-RT & $57.5 \pm 2.3 \%$ \\
\hline RT & Fav-Tw & $54.6 \pm 1.0 \%$ \\
\hline RT & RT-Fol & $55.5 \pm 1.2 \%$ \\
\hline RT & RT-Tw & $58.2 \pm 2.1 \%$ \\
\hline RT & Fav-RT-Fol & $56.2 \pm 1.3 \%$ \\
\hline RT & Fav-RT-Tw & $57.9 \pm 2.9 \%$ \\
\hline RT & Fav-Tw-Fol & $53.1 \pm 1.5 \%$ \\
\hline $\begin{array}{ll}\text { RT } \\
\end{array}$ & RT-Tw-Fol & $56.7 \pm 1.9 \%$ \\
\hline RT & Fav-RT-Tw-Fol & $56.9 \pm 1.9 \%$ \\
\hline $\mathrm{Tw}$ & Fav & $53.8 \pm 3.8 \%$ \\
\hline Tw & Fol & $51.0 \pm 2.5 \%$ \\
\hline Tw & RT & $\mathbf{5 8 . 0} \pm \mathbf{2 . 0} \%$ \\
\hline $\mathrm{Tw}$ & Tw & $59.2 \pm 2.4 \%$ \\
\hline Tw & TAG & $51.4 \pm 11.6 \%$ \\
\hline Tw & Tw-Fol & $56.0 \pm 1.7 \%$ \\
\hline $\mathrm{Tw}$ & Fav-Fol & $51.5 \pm 2.5 \%$ \\
\hline $\mathrm{Tw}$ & Fav-RT & $57.0 \pm 2.0 \%$ \\
\hline Tw & Fav-Tw & $58.7 \pm 2.0 \%$ \\
\hline $\mathrm{Tw}$ & RT-Fol & $53.7 \pm 1.8 \%$ \\
\hline Tw & RT-Tw & $59.9 \pm 2.2 \%$ \\
\hline $\mathrm{Tw}$ & Fav-RT-Fol & $53.5 \pm 2.2 \%$ \\
\hline $\mathrm{Tw}$ & Fav-RT-Tw & $59.1 \pm 1.7 \%$ \\
\hline $\mathrm{Tw}$ & Fav-Tw-Fol & $56.0 \pm 1.8 \%$ \\
\hline $\mathrm{Tw}$ & RT-Tw-Fol & $56.6 \pm 1.6 \%$ \\
\hline Tw & Fav-RT-Tw-Fol & $56.5 \pm 1.4 \%$ \\
\hline
\end{tabular}


き, $V_{O B}$ 内の各ノード $v_{O B}^{(i)},(i=1,2, \ldots, m)$ はオブジェ クトノードによって表現される, 何らかの行為に関与し たある特定のエンティティに相当し， $V_{A C}$ 内の各ノー ド $v_{A C}^{(j)},(j=1,2, \ldots, k)$ はアクションノードによって表 現されるある特定の行為に相当する.エッジ $e^{(i, j)} \in E$ は, $v_{O B}^{(i)} \in V_{O B}$ と $v_{A C}^{(j)} \in V_{A C}$ の間に張られる重みなし のエッジである .すなわち , アクショングラフとは , ア クションノードと, 弚のアクションノードが表現する行 為に関与した全てのオブジェクトノードの間に重みなし の無向エッジが張られるような重みなし無向二部グラフ である . 図 5 にソーシャルメディア上でのユーザの行為 の例と，対応するアクショングラフを示した .

アクショングラフの表現は元の多項関係に表現されて いる三つ以上の共起情報を保持している．なぜなら，あ る行為に相当するアクションノードから出ているエッジ を辿ることで, 兴の行為に関わった全てのエンティティ を特定できるからである .

\section{$3 \cdot 2$ アクショングラフを用いたユーザの興味予測}

続いて,上記で定義したアクショングラフを用いてユー ザの興味を予測する手法について説明する .

推薦タスクにおいては協調フィルタリング [Resnick 94, Shardanand 95] と呼ばれる枠組みがよく用いられている が，協調フィルタリングにおいては，推薦タスクはユー ザとアイテムの間の類似度を計算することでモデル化さ れる . 例えば , 二人のユーザは関与したアイテム集合が 類似していれば似ていると考えられ，あるユーザに対す る推薦は, 兴のユーザと似たユーザが気に入ったアイテ ムの中でまだ光のユーザが関与していないアイテム集合 をもとに行われる.この基本的なアイデアは我々のアク ショングラフに対しても適用できる .二人のユーザの行 為が似ていれば光の二人は似ていると考えるのは自然で ある.従って，協調フィルタリングの枠組みに則り，ユー ザのリソースへの興味を予測する問題を，ユーザの樣々 な行為を活用した上でユーザとリソースの間の類似度を 計算する問題としてモデル化する .

以下で提案手法の詳細を説明する .

オブジェクトノードの総数が $m$, アクションノードの 総数が $k$ のアクショングラフ $G=\left(V_{O B} \cup V_{A C}, E\right)$ が与 えられたとき, $m$ 行 $k$ 列の行列 $\boldsymbol{B}$ を，元のアクショング ラフに対応する二值行列とする . 行列 $\boldsymbol{B}$ の各要素 $\boldsymbol{B}_{i, j}$ は以下のように定義される .

$$
\boldsymbol{B}_{i, j} \equiv \begin{cases}1 & \left(e^{(i, j)} \in E \text { の場合 }\right) \\ 0 & \text { ( } \left.e^{(i, j)} \notin E \text { の場合 }\right) .\end{cases}
$$

まず, ユーザ同士の類似度や，ユーザとリソースの間 の類似度など，エンティティ間の類似度を関与した行為 から計算するために，エンティティ間の初期類似度行列 として $M=B B^{\top}$ を作成する.$M$ の各要素 $M_{i, i^{\prime}}$ は
エンティティ $v_{O B}^{(i)} \in V_{O B}$ とエンティティ $v_{O B}^{\left(i^{\prime}\right)} \in V_{O B}$ が 共起した行為の総数である.

続いて , 行列 $M$ で表現されるグラフ上でエンティティ 間の類似度を伝播させることを考える . 以下で具体例を 用いて説明する．ユーザ $A$ は URL $l$ に対してまだどの ような行為も行っていない状況で, ユーザ $A$ がURL $l$ に どれくらい興味を持つかを予測するために, ユーザ $A$ と URL $l$ の間の類似度を計算することを考える「ユユーザ $A$ がユーザ $B$ と似ており (何らかの行為において共起して おり)，かつ，ユーザ $B$ と URL $l$ も似ている（何らかの 行為において共起している)」ならば，ユーザ $A$ と URL $l$ も似ていると考えられるだろう. 括弧内で示した前提は， 行列 $M$ で表現されるグラフ上でユーザ $A$ と URL $l$ の間 にユーザ $B$ を経由する経路長 2 のパスが存在することと 同値である.ここでは簡単のために経路長 2 に限定した が , これはあらゆる経路長についても言え，また，経路 長が短いほどユーザ $A$ と URL $l$ の類似度は高くなると考 えられる.ここではユーザ $A$ と URL $l$ の間の一つのパス について考えたが, ユーザ $A$ と URL $l$ の間の類似度は， 各パスにより付加される類似度の総和によって決まると 考えられるだろう .

以上のような性質を持つ類似度を行列 $M$ から作成す るために, 本論文ではグラフカーネル [Smola 03]を用い ることを提案する .一部のグラフカーネルは , 二つのノー ド間に存在するパスの数が多ければ产のノード間の類似 度が高くなり，パスの経路長が増えると光のノード間の 類似度が低くなるという性質を持つ. 結果として，二つ のノード間に短いパスが沢山あるほどその二つのノード は類似していると考えられる .

これまて数多くのグラフカーネルか提案されてきた [Smola 03]が, 兴の中でも正則化ラプラシアンカーネルなどのラ プラシアン行列に基づくカーネルが, 関連したノードを見 つけるのに有効であることか指摘されている [Ito 05] . 行 列 $M$ の正則化されていないラプラシアン行列は $D-M$ として定義される .ここで $\boldsymbol{D}$ は $\boldsymbol{D}_{i, i} \equiv \sum_{j} \boldsymbol{M}_{i, j}$ として 定義される対角行列である .このラプラシアン行列に対 して $D^{-\frac{1}{2}}$ を左右から乗ずることで, 対称化された正則 化ラプラシアン行列 $\boldsymbol{L}(\boldsymbol{M}) \equiv \boldsymbol{D}^{-\frac{1}{2}}(\boldsymbol{D}-\boldsymbol{M}) \boldsymbol{D}^{-\frac{1}{2}}$ を得 ることができる．本論文で用いる正則化ラプラシアン行 列は下記のように定義される

$$
\sum_{k=0}^{\infty}\left(-\beta \boldsymbol{L}\left(\boldsymbol{B} \boldsymbol{B}^{\top}\right)\right)^{k}=\left(\boldsymbol{I}+\beta \boldsymbol{L}\left(\boldsymbol{B} \boldsymbol{B}^{\top}\right)\right)^{-1}
$$

ここでBは既に述べたように，オブジェクトノードと

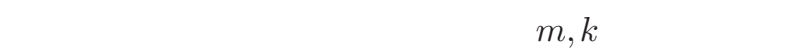
アクショングラフ $G=\left(V_{O B} \cup V_{A C}, E\right)$ に対応する $m$ 行 $k$ 列の二値行列であり, $\boldsymbol{I}$ は $m$ 行 $m$ 列の単位行列であ る.また， $\beta$ はノードペアの類似度を計算する際に離れ たノードにどの程度重みをつけるかを調整するハイパー パラメータである . 正則化ラプラシアンカーネルのほか 
ユーザの行為

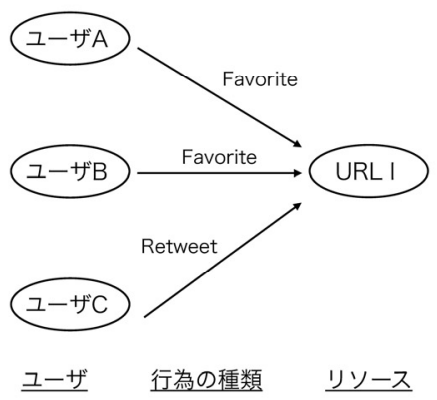

アクショングラフ

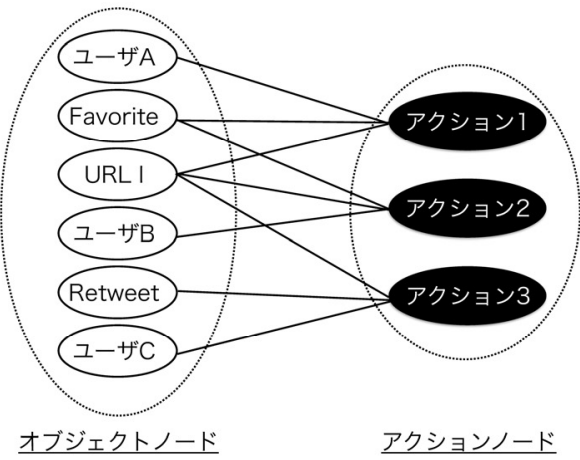

図 5 アクショングラフの構築例

表 3 ユーザの興味予測実験で用いたデータの概要

\begin{tabular}{|c|c|c|c|}
\hline 行為の種類 & 行為数 & エンティティ & エンティティ数 \\
\hline Retweet (RT) & \multirow{2}{*}{14,392} & 行為主体ユーザ & 1,144 \\
& & 言及ユーザ & 7,935 \\
& & URL & 11,335 \\
\hline Favorite (Fav) & \multirow{2}{*}{25,884} & 行為主体ユーザ & 1,161 \\
& & 言及ユーザ & 11,090 \\
& & URL & 20,408 \\
\hline
\end{tabular}

表 4 データのスパースネス

\begin{tabular}{ccc}
\hline 行為の種類 & $\begin{array}{c}\text { スパースネス } \\
\text { (テンソル) }\end{array}$ & $\begin{array}{c}\text { スパースネス } \\
\text { (アクショングラフ) }\end{array}$ \\
\hline \hline Retweet (RT) & $1.4 \mathrm{E}-7$ & $1.5 \mathrm{E}-4$ \\
Favorite (Fav) & $9.9 \mathrm{E}-8$ & $9.2 \mathrm{E}-5$ \\
\hline
\end{tabular}

にも , アクショングラフを用いてユーザの興味を予測す るのに適切であろうグラフカーネルは考えられるが , 本 論文では簡単のため正則化ラプラシアンカーネルに限定 する .

\section{4. 提案手法の評価実験}

本章では, ユーザの興味予測タスクにおいて提案のア クショングラフの性能を評価する実験について述べる .

\section{$4 \cdot 1$ 実 験 条 件}

データセット

クロールの条件は 2 章「ソーシャルメディア上のユー ザの行為の分析」の実験と同一である . 表 3 に今回用いた データ*5 の概要を示した*6. 各行為は“言及ユーザが投 稿した URL を行為主体ユーザが retweet ないし favorite した”ことを示している．

また，表 4 に，テンソルを用いた場合，アクショングラ フを用いた場合の弚れ光れについて，データのスパース

\footnotetext{
*5 norizm.org/datasets.html

*6 Twitter のデータの利活用に関しては右記を参照さ れたい:https://dev.twitter.com/overview/terms/ policy
}

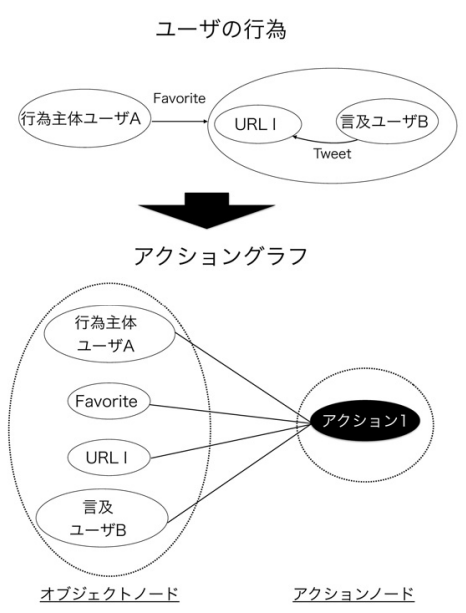

図 6 実験で用いたデータセットに対するアクショングラフの構築例 ネスを表示した . スパースネスを，可能な組み合わせの 中の実際に観測された組み合わせの割合と考えると，テ ンソル , アクショングラフを用いた場合のスパースネス は光れ光れ， $\frac{\left|V_{A C}\right|}{\Pi_{k=1}^{K}\left|E_{\text {Entity }}(k)\right|}, \frac{|E|}{\left|V_{O B}\right|\left|V_{A C}\right|}$ として定義され る .ここで, Entity ${ }^{(k)}$ は, 各エンティティのクラス (今 回のデータでは , 行為主体ユーザ/URL㢇及ユーザの三 種類) ごとにまとめたオブジェクトノードの集合を表す . 今回のデータでは, Entity ${ }^{(1)}$, Entity $^{(2)}$, Entity $^{(3)}$ が光 れどれ，行為主体ユーザ集合， $U R L$ 集合，言及ユーザ集 合である . || は集合のサイズを表す . 今回の定義ではス パースネスの值が大きいほどスパースネスが緩和される ことになる．アクショングラフを用いた場合のスパース ネスはテンソルを用いた場合のスパースネスの 1,000 倍 となっており，アクショングラフを用いることでスパー スネスが大幅に緩和されていることが確認できる .

また，今回のデータセットに対するアクショングラフ の構築例を図 6 に示した .

予測設定

ユーザがウェブ上のあるリソースに対して何らかの行 為を行ったとき, 兴のユーザは光のリソースに対して興 
味を抱いたと考えることができる．本害験では，ユーザ の興味予測を, ユーザが各リソースに対して抱く興味の 度合い, すなわち，ユーザが各リソースに対してどれく らい retweet ないし favorite の行為を行い光うかの度合 いをユーザとリソースの類似度をもとに予測する問題と して定義する．

入力は関係データのタプルであり，タプルが与えられ ればアクショングラフを構築することができる.出力は エンティティ間の類似度である.我々は, あるユーザが あるリソースにどれくらい興味を持つかを, 光のユーザ とリソースの間の類似度をもとにして予測する . 前述の 実験と同樣に 30 日間のデータを 3 日ごとに区切った 10 個のスロットを作り，スロット $t \in[1,9]$ のデータを訓練 データとし，スロット $t+1 \in[2,10]$ のデータを評価デー タとした . 今回の実験では 3 日間でサンプリングしたデー タを使うが, 提案手法は特定のサンプリング間隔を前提 としない

比較手法

我々は提案手法を五つのベースラインと比較した . 提 案手法および五つの比較手法について表 5 にて整理した 。 比較の観点としては, 関係モデルとして多項関係と二項 関係があり，さらに手法の分類としてグラフに基づく手 法か否かがある . 関係モデルというのは, ユーザのリソー スへの興味を予測するにあたり，ユーザの行為をユーザ とリソースの二項関係として捉え予測に活用するのか， 兴れ以外の情報 (発信元ユーザや行為の種類) を踏まえ た多項関係として捉え予測に活用するのかを比較するた めの項目である.グラフに基づく手法に関してはどのよ うなグラフを構筑したかで, アクショングラフ , 二部グ ラフ, クリーク拡張の三つを挙げている .これらのグラ フに基づく手法において適用するアルゴリズムは提案手 法と同一である .これらの手法間の結果を比較すること で , (a) ユーザの行為を多項関係として捉え予測に活用す ることで, 二項関係として捉える場合よりも予測の性能 を向上させることができるか，(b) 同じ情報を用いてい ても構築するグラフによりアルゴリズムの性能か変わる かを確認できると期待できる.特に，提案手法と比較手 法 (3) AG-binomial で異なるのは関係モデルのみである ので, これら二つの結果を比較することで上記 $(a)$ を確認 できる．また，提案手法と比較手法 (2) Clique Expansion で異なるのはグラフの構築方法のみであるので, これら 二つの結果を比較することで上記 $(b)$ を確認できる．以 下で各手法の詳細を説明する。

多項関係を扱うのに近年盛んに用いられているのがテ ンソル分析であり，弚の中でも標準的な手法の一つであ る (1) PARAFAC [Bader 06] を多項関係の分析手法の代 表として採用した . PARAFACを用いることで各オブジェ クトは潜在空間に射影される。本実験では，PARAFACに よって得られたユーザと $U R L$ の潜在ベクトルのコサイン 類似度によってユーザと URL の類似度を計算した . (2)
Clique Expansion [Zien 99] は, 元の $N$ 項から成る多項 関係を二項の全組み合わせに分解し，提案手法と同一のア ルゴリズム (正則化ラプラシアンカーネル) を適用した手 法である ここれは,多項関係をペアワイズな二項関係に分 解するのではなく，もともとの多項の共起を保存すること が予測の精度やデー久過疎への頑健性といった性能の向 上に有効であるかどうかを評価するために採用した . (3) AG-binomial は , 行為主体のユーザと URL のみからアク ショングラフを構築し提案手法と同一のアルゴリズムを 適用した手法である .これは, ユーザの行為をユーザとリ ソースの二項関係として捉えるのではなく，ほかのエン ティティも巻き込む多項関係として捉えることが予測の精 度やデー夕過疎への頑健性といった性能の向上に有効で あるかどうかを評価するために採用した . (4) LDA [Blei 03] は，確率的生成モデルの一つであり，観測データは トピックと呼ばれる未観測の潜在変数によって説明され る．あるユーザ $u$ があるリソース $(U R L) r_{i}$ に興味を持 つ確率は $P\left(r_{i} \mid u\right)=\sum_{j=1}^{Z} P\left(r_{i} \mid z_{i}=j\right) P\left(z_{i}=j \mid u\right)$ とし て計算される .ここで $P\left(r_{i} \mid u\right)$ は, ユーザ $u$ が与えられ た時の $i$ 番目の $U R L$ の条件付き確率であり， $z_{i}$ はトピッ クである . LDA は二項関係を対象とする標準的な手法で あるため, 既存の二項関係の分析手法の代表として採用 した . (5) Bipartite Graph は, ユーザとリソースの二部 グラフに対して提案手法と同一のアルゴリズムを適用し た手法であり，二項関係を対象とする既存手法の中の一 つとして採用した .

\section{評価指標}

予測精度の評価には R-Precision [Craswell 09] を,デー 夕過疎への頑健性の評価には被覆率 [Ge 10] 用いた . 以下で詳細を説明する.$R$-Precision は， $R$ を正例のデー 夕数とした時に上位 $R$ 個について評価した際の precision (精度) である. 各スロットとユーザについて $R$ Precision の平均を計算した .この際，行為数が 0 とな るユーザは計算の対象外とした . 各ユーザについての正 例は, retweet/favorite の行為を行った URLである.被覆 率は, 評価データ中で類似度を計算できたユーザと $U R L$ のペアの割合を示す . 推薦システムにおいては , 推薦す ベきアイテムを見落とさないことが重要である場面はし ばしばあり，被覆率は特に弚のような状況における推薦 システムの性能の評価に用いられている．また，被覆率 は推薦システムのコールドスタート問題における対処の 度合いを評価するのにも有効である．なぜかというと， データが過疎なユーザやアイテムに対しては光も光も予 測值が得られない状況がしばしば起こるため, 兴のような 疎なデータに対しても予測值を得られること自体がデー 夕過疎に対する頑健性として考えられるからである $. R-$ Precision と同樣に , 各スロットとユーザについて被覆率 の平均を計算した . 
表 5 実験で用いた手法の比較

\begin{tabular}{|c|c|c|c|c|c|}
\hline & \multirow{2}{*}{ 関係モデル } & \multirow{2}{*}{ グラフに基づく手法 } & \multicolumn{3}{|c|}{ グラフに基づく手法で構築しているグラフ } \\
\hline & & & アクショングラフ & 二部グラフ & クリーク拡張 \\
\hline 提案手法 & 多項 & $\checkmark$ & $\checkmark$ & & \\
\hline (1) PARAFAC & 多項 & & & NA & \\
\hline (2) Clique Expansion & 多項 & $\checkmark$ & & & $\checkmark$ \\
\hline (3) AG-binomial & 二項 & $\checkmark$ & $\checkmark$ & & \\
\hline (4) LDA & 二項 & & & NA & \\
\hline (5) Bipartite Graph & 二項 & $\checkmark$ & & $\checkmark$ & \\
\hline
\end{tabular}

ハイパーパラメータ設定

全データの $20 \%$ をチューニング用データとしてランダ ムにサンプリングし，このデータを用いてR-Precision を 評価指標として提案手法と比較手法のハイパーパラメー タを調整した . $\beta$ を $0.01,0.05,0.1$ の三つから調整した 結果ほぼ同じ値となったが , $\beta=0.01$ のときが若干精度 が高かったため， $\beta$ は 0.01 で固定した . 正則化ラプラ シアンカーネルがハイパーパラメータ $\beta$ に対して安定し ていることは指摘されており [Ito 05], 今回の実験でも そのことが確認された . PARAFACにおいては潜在次元 数を 200,400,600,800 で調整した結果最も R-Precision の高かった 600 で固定した . LDA ではトピック数のほ か $\alpha$ と $\beta$ という二つのハイパーパラメータが存在する. $L D A$ をドキュメントの生成モデルとして用いるとき $\alpha$ は各ドキュメントにおけるトピックのディリクレ事前分 布のハイパーパラメータであり， $\beta$ は各トピックにおけ る単語のディリクレ事前分布のハイパーパラメータであ る . $L D A$ においてはトピック数を $100,200,400,600$ で， $\beta$ を 0.01,0.05, 0.1 て調整した結果，最も R-Precision の 高かったトピック数 400 と $\beta=0.01$ で固定した . トピッ ク数に応じて $\alpha$ を変化させることが有効であることが指 摘されているので [Wallach 10] , 今回の実験でも , ライ ブラリとして用いた $p L D A^{* 7}$ の実装に従い各トピックに ついて $\alpha$ は $\frac{50}{\text { topicNumber }}$ として計算した .

\section{$4 \cdot 2$ 結 果}

表 6 に各手法の精度 (R-Precision) と被覆率の平均值を した . 提案手法と比較手法の各ペアについて $t$ 検定を行 い有意 $(p<0.05)$ であった手法が太文字で示されている.

予測精度については提案手法が他の全ての手法よりも 有意に高い精度を実現していることが確認できる.被覆 率については，提案手法は Clique Expansion に対しては 有意差のない結果となったが，乥れ以外の全ての手法に 対しては有意に高い被覆率となった . 特に,PARAFAC と Clique Expansion 以外のグラフに基づく手法 (Bipartite Graph とAG-binomial) に対しては提案手法は乥れらを 大きく上回る被覆率となった . 提案手法を大きく下回る 被覆率となった二つのグラフに基づく手法は, ユーザと

*7 code.google.com/p/plda
$U R L$ の二項関係のみモデル化した手法である . 提案手法 がこれらの手法を大きく上回る被覆率を実現した理由と して, 行為の種類 (retweetやfavorite) や original-tweetuser ，すなわち URL を発信したもともとのユーザといっ た情報が有効に機能したことが考えられる. 二項関係を 予測する際にも元の多項関係を活用することで被覆率の 向上が可能になることが示唆される

また , 提案手法が他のグラフに基づく手法の全てに対 して総じて高い予測精度や被覆率を実現したことは特筆 すべきである . グラフを用いてユーザとリソースの間の 類似度を計算する研究はこれまで多々なされてきたが, 本 実験は，適用するアルゴリズムの性能は光も光も構筑す るグラフの選択に大きく依存することを示している．

以下で特に 4.1 節の実験条件にて述べた以下の二点： (a) ユーザの行為を多項関係として捉え予測に活用する ことで, 二項関係として捉える場合よりも予測の性能を 向上させることができるか, $(b)$ 同じ情報を用いていても 構筑するグラフによりアルゴリズムの性能か変わるかに ついて結果を説明する。

提案手法と比較手法 (3) AG-binomial で異なるのは関 係モデル (二項/多項) のみであるので，これら二つの結 果を比較することで上記 $(a)$ を確認できるが，予測精度 と被覆率のどちらに関しても提案手法は (3) AG-binomial を有意に上回る結果となった . 以上から , (a) ユーザの行 為を多項関係として捉え予測に活用することで，二項関 係として捉える場合よりも予測の精度や被覆率を向上さ せることができることが示唆された . また, 提案手法と 比較手法 (2) Clique Expansion で異なるのはグラフの構 築方法のみであるので, これら二つの結果を比較するこ とで上記 $(b)$ を確認できるが，被覆率に関しては両者に 有意差は確認できなかったものの，予測精度に関しては， 提案手法が (2) Clique Expansion よりも有意に高い値と なっていることが確認できる，以上から，同じ情報を用 いていても構築するグラフによりアルゴリズムの予測精 度が変わることが示唆された。 
表 6 各手法における精度と被覆率の比較 $(t$ 検定 $(p<0.05)$ で觉の他の手法に対して有意であつた手法の結果 が太字で表記されている)

\begin{tabular}{ccccccc}
\hline & 提案手法 & PARAFAC & Clique Expansion & AG-binomial & LDA & Bipartite Graph \\
\hline \hline R-Precision (精度) & $\mathbf{7 . 6} \%$ & $3.4 \%$ & $4.2 \%$ & $4.2 \%$ & $4.3 \%$ & $2.0 \%$ \\
\hline Coverage (被覆率) & $\mathbf{9 9 . 8} \%$ & $43.6 \%$ & $\mathbf{9 9 . 8} \%$ & $41.9 \%$ & $99.0 \%$ & $56.4 \%$ \\
\hline
\end{tabular}

\section{5. 関 連 研 究}

多項関係を扱うことで三つ以上のエンティティの間の 共起を捉えることができる.例えば二人の人間があるド キュメントに対して同一のタグを付けた場合でも，乥れ

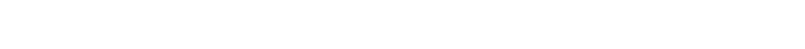
だろう・タグとドキュメントの二項関係だけでなくユーザ を踏まえた三項関係 (多項関係) を表現することで,上記 の事実を反映した知見の抽出や予測モデルの構築が期待 できる . 規模の大きなデータに対して多項関係を扱う主 要な方法は大きく, テンソル分析を用いた手法と多項関 係をペアワイズの二項関係に分解して分析する手法の二 つに分けることができる . 二項関係をペアワイズに分解 することで既存の行列やグラフに基づく手法による解析 が可能となる . 例としては, 論文推薦を行うにあたって， 著者, 論文, 会議の三項関係をペアワイズの二項関係に分

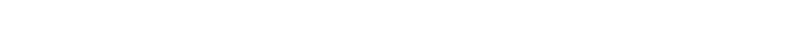
題として定式化した研究 [Zhou 08]や, ユーザとリソー スとタグの三項関係を一つの三部グラフや二つの二部グ ラフで表現しグラフアルゴリズムを適用した研究 [Hotho 06, Zhang 10] などが挙げられる .

しかし , これらのペアワイズな手法では元々の多項関係 の共起情報が欠損してしまうという欠点がある.多項関 係を保持した上で解析するアプローチとしてテンソル分 解は近年盛んに研究されており [Kolda 09] , 樣々なテン ソル分解手法が, $C P$ 分解や Tucker 分解などの樣々な分 解モデル, カルバック・ライブラー情報量やユークリッド 距離などを用いた樣々な損失関数, 弚して樣々な最適化手 法とともに提案されている.特にウェブマイニングの分野 では Symeonidis ら [Symeonidis 08] と Rendle ら [Rendle 09]が Tucker 分解に基づいたタグ推薦のためのテンソル 分解手法を提案した. 弚のほか, Lin らは非負值行列分 解をテンソルの場合に拡張し, ソーシャルメディア上で のコミュニティ抽出に適用した [Lin 09] .

以上のようにテンソル分解を用いた手法は近年盛んに 研究されているが, 本論文ではテンソルではなくグラフ を用いて多項関係を解析しており，二項関係を対象とし たグラフに基づく従来手法を基に，多項関係への拡張を 可能にするという点で光れらのアプローチと異なる．以 下でこの点について述べる . ユーザにアイテムを推薦す るタスクや , ソーシャルメディア上でのユーザの興味や 行動を予測するタスクに対しては, 協調フィルタリング の基になっている “自分と似たアイテムを気に入るユー
ザの気に入るアイテムは自分も気に入るだろう”といっ たような何らかの仮説を基に手法か構築されていること が多く，対象とするデータの特徵を踏まえた種々の仮説 が考えられ，弚の仮説を基にした手法の有効性も検証さ れてきた．しかし，弚れらの多くは二項関係をモデル化 したものであるか，多項関係を二項の全組み合わせに分 解した上でのモデル化であった . 基となっている種々の 仮説には一定度の有効性があると期待できるので, 弚れ らの仮説を基に二項関係だけでなく多項関係もモデル化 できるように拡張することは有意義であろう.特に，こ れまでの手法ではユーザとリソースの二項関係を主に対 象としてきたのに対して , 本論文ではエンティティと行 為の二項関係という見方を導入することで多項関係をモ デル化しグラフとして表現しているので，この見方を基 にこれまで提案されてきたグラフに基づく手法を多項関 係に対して拡張することも可能だろう . 今回の例でいえ ば，我々は推薦システムで普及している協調フィルタリ ング [Resnick 94, Shardanand 95] のアイデアを拡張した と言える．協調フィルタリングの基本的アイデアは，人 とアイテムの二項関係があるときに，一方 (人同士もし くはアイテム同士) の類似度を他方の観点から評価する ことである . 基になっているのは“似たようなアイテム を好む人同士は似ている”という仮説である .この仮説 を基に，あるユーザと似た他のユーザが気に入るアイテ ムを兴のユーザに推薦している，我々は，アイテムを行 為に拡張し “行為が似ている人同士は似ている”という仮 説を導入した上で, 人と行為をグラフによって表現する ことで, グラフに基づくアルゴリズムを上記の拡張した 仮説に沿う形で応用したと解釈できる。

最後に, 本論文のベースとなっている著者らの研究 $[N o r i$ $11 b$, Nori 11a] と本論文の関係について説明する . [Nori $11 b]$ では, 本論文 1.4 節の「本論文の貢献」の (4) で述 べた以下の点について独自の知見を得ている.すなわち， グラフを用いてユーザ間やユーザとリソース間の類似度 を求めるためのアルゴリズムは多々提案されてきたが， 本論文では, グラフを用いたアルゴリズムの性能はそも そもどのようなグラフを構築するかに依存すること，ま た，ユーザの行動に関与する樣々なエンティティの情報 をグラフに付与することでグラフマイニングのアルゴリ ズムを効果的に機能させることができることを示した点 である .この点は本論文の主要な貢献となる知見である . [Nori 11a] では, 本論文 1.4 節の「本論文の貢献」の (1) で述べた点に関して, ユーザの行動分析を網羅的に行っ 
た結果として独自の知見を得ている．また，[Nori 12]で は，多項関係予測において課題となるデータの疎性に対 処するために，接続行列を用いて本論文と同樣に多項関 係を二項関係に変換した上で, 理論的大域解を保証する 手法を提案している.

\section{6.お おりに}

本論文では, ソーシャルメディア上でのユーザの行為 データからの興味予測という問題設定を行い, 兴の意義 や応用可能性について述べた .上記のタスクを解くにあ たって課題となる点として，データのアグリゲーション に関する知見を得る必要性と多項関係データを活用する データ過疎に頑健な手法を構築する必要性の二点を述べ た . 前者の課題に対しては分析のための実験方法を提案 し, 複数のウェブサービスの複数の行為を含む実データ を用いた実験を行うことでいくつかの知見を得た . 後者 の課題に対してはアクショングラフという, ユーザの樣々 な行為を多項関係として表現できる新しいグラフ表現を 提案し, 乥のグラフを用いた予測手法を提案した。乥し て現実のソーシャルメディアのデータを用いて提案手法 の予測精度やデータ過疎への頑健性を評価し, 提案手法 が樣々なベースラインを上回る性能を実現することを確 認した . グラフを用いてユーザ間やユーザとリソース間 の類似度を求める研究は数多くなされてきたが, 本実験 の結果により，グラフを用いたアルゴリズムの性能は光 も光もどのようなグラフを構築するかに依存すること， また, ユーザの行動に関与する樣々なエンティティの情 報をグラフに付与することでグラフマイニングのアルゴ リズムを効果的に機能させることができることが示唆さ れた .

\section{$\diamond$ 参 考 文 献 $\diamond$}

[Bader 06] Bader, B. W. and Kolda, T. G.: Algorithm 862: MATLAB tensor classes for fast algorithm prototyping, TOMS, Vol. 32, No. 4, pp. 635-653 (2006)

[Bao 07] Bao, S., Xue, G., Wu, X., Yu, Y., Fei, B., and Su, Z.: Optimizing web search using social annotations, in Proceedings of the 16th International Conference on World Wide Web, $W W W$ '07, $p p$. 501-510 (2007)

[Blei 03] Blei, D. M., Ng, A. Y., and Jordan, M. I.: Latent Dirichlet Allocation, Journal of Machine Learning Research, Vol. 3, pp. 993 1022 (2003)

[Craswell 09] Craswell, N.: R-Precision, in Encyclopedia of Database Systems, pp. 2453-2453 (2009)

[Ge 10] Ge, M., Delgado-Battenfeld, C., and Jannach, D.: Beyond Accuracy: Evaluating Recommender Systems by Coverage and Serendipity, in Proceedings of the fourth ACM Conference on Recommender Systems, RecSys '10, pp. 257-260 (2010)

[Heymann 08] Heymann, P., Koutrika, G., and Garcia-Molina, H.: Can social bookmarking improve web search?, in Proceedings of the first International Conference on Web Search and Web Data Mining, WSDM '08, pp. 195-206 (2008)

[Hotho 06] Hotho, A., Jäschke, R., Schmitz, C., and Stumme, G.: FolkRank: A Ranking Algorithm for Folksonomies, in LWA, pp. 111114 (2006)
[Ito 05] Ito, T., Shimbo, M., Kudo, T., and Matsumoto, Y.: Application of kernels to link analysis, in Proceedings of 11th ACM SIGKDD Conference on Knowledge Discovery and Data Mining, KDD '05, pp. 586-592 (2005)

[Jiang 12] Jiang, M., Cui, P., Wang, F., Yang, Q., Zhu, W., and Yang, S.: Social Recommendation Across Multiple Relational Domains, in Proceedings of the 21st ACM Conference on Information and Knowledge Management, CIKM '12, pp. 1422-1431 (2012)

[Kolda 09] Kolda, T. G. and Bader, B. W.: Tensor Decompositions and Applications, SIAM Review, Vol. 51, No. 3, pp. 455-500 (2009)

[Lin 09] Lin, Y.-R., Sun, J., Castro, P., Konuru, R., Sundaram, H., and Kelliher, A.: MetaFac: community discovery via relational hypergraph factorization, in Proceedings of 15th ACM SIGKDD Conference on Knowledge Discovery and Data Mining, KDD '09 (2009)

[Ma 11] Ma, H., Zhou, D., Liu, C., Lyu, M. R., and King, I.: Recommender Systems with Social Regularization, in Proceedings of the fourth International Conference on Web Search and Web Data Mining, WSDM'11, pp. 287-296 (2011)

[Mika 05] Mika, P.: Ontologies Are Us: A Unified Model of Social Networks and Semantics, in Proceedings of the fourth International Semantic Web Conference, Vol. 3729 of ISWC '05, pp. 522-536 (2005)

[Nocedal 80] Nocedal, J.: Updating quasi-Newton matrices with limited storage, Mathematics of Computation, Vol. 35, No. 151, pp. 773782 (1980)

[Nori 11a] Nori, N., Bollegala, D., and Ishizuka, M.: Exploiting User Interest on Social Media for Aggregating Diverse Data and Predicting Interest, in Proceedings of the fifth International Conference on Weblogs and Social Media, ICWSM '11, pp. 241-248 (2011)

[Nori 11b] Nori, N., Bollegala, D., and Ishizuka, M.: Interest Prediction on Multinomial, Time-Evolving Social Graphs, in Proceedings of the 22nd International Joint Conference on Artificial Intelligence, IJCAI'11, pp. 2507-2512 (2011)

[Nori 12] Nori, N., Bollegala, D., and Kashima, H.: Multinomial Relation Prediction in Social Data: A Dimension Reduction Approach, in Proceedings of the 26th AAAI Conference on Artificial Intelligence, AAAI'12, pp. 115-121 (2012)

[Rendle 09] Rendle, S., Balby Marinho, L., Nanopoulos, A., and Schmidt-Thieme, L.: Learning optimal ranking with tensor factorization for tag recommendation, in Proceedings of the 15th ACM SIGKDD International Conference on Knowledge Discovery and Data Mining, KDD '09, pp. 727-736 (2009)

[Resnick 94] Resnick, P., Iacovou, N., Suchak, M., Bergstrom, P., and Riedl, J.: GroupLens: An Open Architecture for Collaborative Filtering of Netnews, in Proceedings of the 1994 ACM Conference on Computer Supported Cooperative Work, pp. 175-186 (1994)

[Schifanella 10] Schifanella, R., Barrat, A., Cattuto, C., Markines, B., and Menczer, F.: Folks in Folksonomies: social link prediction from shared metadata, in Proceedings of the third ACM International Conference on Web Search and Data Mining, WSDM '10, pp. 271-280 (2010)

[Shardanand 95] Shardanand, U. and Maes, P.: Social Information Filtering: Algorithms for Automating "Word of Mouth", in Proceedings of the SIGCHI Conference on Human Factors in Computing Systems, pp. 210-217 (1995)

[Smola 03] Smola, A. J. and Kondor, R.: Kernels and regularization on graphs, Springer (2003)

[Symeonidis 08] Symeonidis, P., Nanopoulos, A., and Manolopoulos, Y.: Tag recommendations based on tensor dimensionality reduction, in Proceedings of the second ACM Conference on Recommender Systems, RecSys '08, pp. 43-50 (2008)

[Wallach 10] Wallach, H. M., Mimno, D., and Mccallum, A.: Rethinking LDA: Why Priors Matter, in Proceedings of the 23rd Annual Conference on Neural Information Processing Systems, NIPS '10 (2010) [Xu 08] Xu, S., Bao, S., Fei, B., Su, Z., and Yu, Y.: Exploring folksonomy for personalized search, in Proceedings of the 31st Annual International ACM SIGIR Conference on Research and Development in Information Retrieval, SIGIR '08, pp. 155-162 (2008)

[Yang 11] Yang, S.-H., Long, B., Smola, A., Sadagopan, N., Zheng, Z., and Zha, H.: Like Like Alike: Joint Friendship and Interest Propagation in Social Networks, in Proceedings of the 20th International 
Conference on World Wide Web, WWW'11, pp. 537-546 (2011)

[Zhang 10] Zhang, Z.-K., Zhou, T., and Zhang, Y.-C.: Personalized recommendation via integrated diffusion on user-item-tag tripartite graphs, Physica A: Statistical Mechanics and its Applications, Vol. 389, No. 1, pp. 179-186 (2010)

[Zhou 08] Zhou, D., Zhu, S., Yu, K., Song, X., Tseng, B. L., Zha, H., and Giles, C. L.: Learning multiple graphs for document recommendations, in Proceedings of the 17th International Conference on World Wide Web, WWW'08, pp. 141-150 (2008)

[Zien 99] Zien, J. Y., Schlag, M. D. F., and Chan, P. K.: Multilevel spectral hypergraph partitioning with arbitrary vertex sizes, IEEE Transactions on Computer-Aided Design of Integrated Circuits and Systems, Vol. 18, No. 9, pp. 1389-1399 (1999)

\section{〔担当委員：篠田 孝祐〕}

\section{4 年 7 月 23 日 受理}

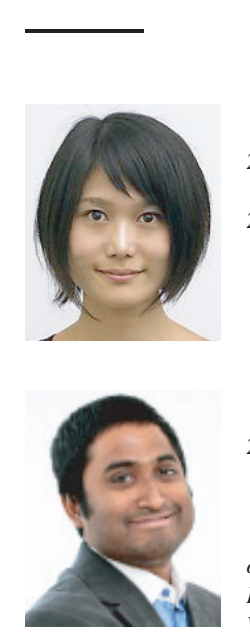

\section{紹 介}

\section{則 のぞみ(学生会員)}

2010 年東京大学工学部システム創成学科卒業 . 2012 年同 大学院情報理工学系研究科創造情報学専攻修士課程修了。 2014 年より京都大学大学院情報学研究科知能情報学専攻 博士課程および学術振興会特別研究員 $(D C 1)$. 統計的機 械学習とデータマイニング,ヘルスケアへの応用に興味を 持つ

\section{ボレガラ ダヌシカ (正会員)}

2005 年東京大学工学部電子情報工学科卒業. 2007 年同 大学院情報理工学系研究科修士課程修了. 2009 年同研究 科博士課程修了. 博士 (情報理工学) . 東京大学大学院 情報理工学系研究科助教, 講師を経て, 現在は University of Liverpool (Department of Computer Science) の Senior Lecturer (Associate Professor). 自然言語処理に興味を持つ。 $W W W, A C L, E C A I$ などの会議を中心に研究成果を発表 .

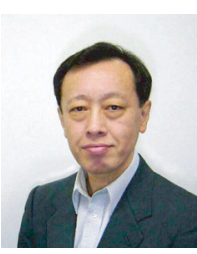

\section{石塚 満(正会員)}

1971 年東京大学工学部卒業, 1976 年同大学院工学系研究 科博士課程修了. 工学博士. 同年 NTT 入社, 横須賀研究 所勤務. 1978 年東京大学生産技術研究所助教授 (1980-81 年 Perdue 大学客員准教授) . 1992 年同大学工学部電子情 報工学科教授. 2001 年同大学院情報理工学系研究科教授. 2013 年定年退職, 東京大学名誉教授. 2014 年早稲田大学 基幹理工学研究科教授 (エジプト日本科学技術大学担当). 研究分野は人工知能, Web インテリジェンス, 意味計算, 生命的エージェントによるマルチモーダルメディア．IEEE，AAAI，電子情報通 信学会, 情報処理学会等の会員 . 本会元会長 . 